\title{
SALMON RECOVERY AND FISHERIES MANAGEMENT: THE CASE FOR DAM BREACHING ON THE SNAKE RIVER
}

\author{
Meredith Gore \& Patricia Doerr
}

\begin{abstract}
For centuries, Pacific salmonids have been migrating up and down the Columbia and Snake Rivers. Unfortunately and for various reasons, most notably the erection of numerous dams along these rivers, the size of several populations of Pacific salmonids has dramarically decreased in the past several decades. Currencly all five species of Snake River salmon are listed under the Endangered Species Act, and no holistic extincrion prevention or recovery plan exists. This paper examines four policy alternatives to determine which would constitute the most comprehensive, holistic, and timely recovery plan for these endangered Snake River salmon. This recovery plan should not only prevent extinction of the listed salmon populations, but should eventually result in the delisting of these species. After a review of the four alternatives and an examination of the political climate surrounding this contentious issue, it is concluded that the four dams on the Lower Snake River must be breached. Further, certain elements from the aggressive nonbreach alternative should be implemented in conjunction with dam removal to ensure that each of the 4-H's (habitat, hatchery, harvest and hydropower) are addressed such that salmon are given a better chance at recovery.
\end{abstract}

If our salmon runs are not healthy, then our watersheds are not bealthy. And if our watersheds are not bealthy, then we are putting at risk our future and that of our children and grandchildren.

-Oregon Governor John Kitzhaber

\section{Introduction}

The clear, cold, oxygen-rich waters of the Pacific Northwest's rivers and tributaries have allowed salmon to thrive and have provided it with an ecological and economic bounty. The significance of salmon to the economy, culture, and ecology of the Pacific Northwest can be evidenced from Alaska to

Meredith Gore holds a Bachelor of Arts degree in Anthropology and Environmental Studies from Brandeis University and received the Rachel Carson Award for Environmental Citizenship. She is a candidate for a Master of Arrs degree in Environmental and Natural Resource Policy ar The George Washington University. Ms. Gore is a species conservation assistanc at Defenders of Wildlife.

Patricia Doerr has a Bachelor of Science degree in Environmencal Policy and Natural Resource Management from Rutgers Universiry-Cook College. Currently, she is a candidate for a Master of Arrs degree in Environment and Resource Policy at The George Washington Universiry, and works for the Senare Commitree on Environment and Public Works.
California. In ecological terms, the fish serve as a natural nutrient recycler by transporting the organic material they eat in the oceans and store in their bodies into the watersheds. Salmon die in the rivers shortly after spawning, allowing their nutrients to be used by insects, bears, plants, trees, and baby salmon. For Native American tribal groups, the salmon have been an integral part of their cultural history and traditions for centuries. Economically, salmon have boosted regional economies since the colonial era, facilitating rapid growth of commercial fisheries and salmon canneries.

Today, four species of salmon and trout living in the Lower Snake River are endangered; the spring/summer chinook salmon, sockeye salmon, fall chinook, and steelhead trour were all listed as threatened within the past seven years and one species, the coho salmon, has gone biologically extinct. When a species is listed endangered or threatened under the Endangered Species Act (ESA), a recovery plan must be developed. Because these salmon have such economic, ecological, and cultural significance in the Pacific Northwest, the formulation of their extinction prevention and recovery plan is of the utmost importance.

The recovery plan for the salmon has also been the focus of a contentious debate. Many scientists, tribes, and government officials argue that a significant factor leading to the decline of Snake River salmon populations is the large number of dams that have been erected along the Columbia and 
Snake Rivers during this century for hydropower, transportation, and irrigation purposes. Four specific dams on the Lower Snake River are at the center of a debate that is sure to influence environmental resource policy for years to come. Is dam removal the solution to saving these salmon populations? Or will other options, such as habitat and hatchery improvements, suffice?

In order to properly evaluate dam removal as a possible solution for saving salmon, we must also examine other popular, potentially viable solutions. Important questions that must be asked of each potential solution include how, when implemented as policy, the solution will contribute to a comprehensive, holistic, and timely recovery plan for the endangered Snake River salmon and steelhead trout. Also, does the proposed solution reflect the most current input from scientists, citizens, tribes, and government agencies? And, finally, does the recovery plan attempt to prevent extinction of the listed salmon and steelhead populations while furthering the eventual goal of delisting these species?

The four dams in question-the Ice Harbor, Lower Monumental, Little Goose, and Lower Granite dams-were built between 1962 and 1975 . They were originally erected by the Bonneville Power Administration (BPA) to provide cheap hydroelectric power, water for irrigation, and a system to transport goods on barges upriver to Lewiston, Idaho. They are located between the Snake River's confluence with the Columbia River in Washington State and the Idaho border, impacting a 140-mile stretch of prime river habitat.

The presence of the dams has dramatically impacted the salmon populations for the worse. Indeed, since the installation of the last dam in 1975, Snake River salmon runs have declined by 90 percent. ${ }^{1}$ The dams create numerous potential threats to the salmon populations. Both adult and juvenile salmon must cope with changes in water quality and habitat caused by the dams, including increased temperature, increased turbidity, and decreased water velocity. Each dam creates a slack water reservoir behind it, causing the waters in these reservoirs to move much slower than in a free-flowing river and water temperatures to rise, especially in the summer.

Most recovery efforts for salmon in the Pacific Northwest focus on remediating the adverse effects of actions of the human populations; the rapid decline of the once-numerous salmon runs can be traced to the economic development of the area. Human activities that have contributed to the decline of the salmon populations are classified as "the 4-Hs"-habitat, harvest, hatcheries, and hydropower.
Habitat alterations that have adverse effects include forestry, agriculture, and mining. People have harvested salmon for subsistence, recreation, and commercial use, which reduces the number of adult salmon that return to the river to spawn. Hatcheries have compromised the genetic diversity of salmon species through inbreeding and competition. Finally, hydropower construction along the various rivers has impeded salmon migration and decreased water quality.

\section{Stakeholders}

A variety of stakeholders are involved in this issue, including environmental interest groups, state and federal regulatory agencies, Congress, commercial fisheries, sport fishermen, and tribal groups. Groups that advocate dam removal as a minimum necessary step towards saving salmon include a large coalition of at least nine "green" groups (American Rivers, EarthJustice, Defenders of Wildlife, National Wildlife Federation, National Resource Defense Council, Save Our Wild Salmon Coalition, Sierra Club and more) and two national non-governmental organizations (Trout Unlimited and Taxpayers for Common Sense). Some Native American tribes, such as the Nez Perce, whose reservation is adjacent to the City of Lewiston, similarly advocate breaching the dams since salmon remain an integral part of their tribal culture and economy. Other tribes that stand to be affected by salmon extirpation include the Shoshone-Bannock Tribes of the Fort Hall Reservation, the Confederated Tribes of the Umatilla Reservation, the Yakama Indian Nation, and the Confederated Tribes of Warm Springs Reservation of Oregon. The total loss of the salmon populations would impact the tribal ceremonies, subsistence, and commercial harvesting of these tribes.

Not surprisingly, the residents of Lewiston, Idaho are primarily against dam removal. The four Lower Snake River dams created a bustling riverport out of Lewiston, and the town contends that removing the dams will force many people out of work. Without the dams to create the riverport, people may be forced to leave Lewiston to find alternative means of employment and leave a desolated town in their wake.

Various political figures have voiced support in favor of dam removal. Not all have directly stated their opposition or support, but there is general consensus in some states. Alaska Governor Knowles and Oregon Governor Kitzhaber are known to support the idea of dam removal. Other politicians oppose the action, including Idaho Governor Kempthorne and Senators Mike Crapo and Larry Craig, 
and Washington Governor Gary Locke and Senators Slade Gorton and Patty Murray. Their opposition stems mainly from the economic implications of such an action.

\section{Current Policy}

The current salmon recovery policy focuses on transporting smolts, or juvenile salmon, downstream in trucks or barges. The concept of barging and trucking salmon smolts is fairly simple. As the juveniles migrate downstream they are collected into barges or trucks above the dams, transported downstream past the dams, and then released back into the river below the lowest dam. In order to collect the juvenile fish into the barge or truck, they are sucked into powerhouse intakes where 20-foot long screens divert the fish into a bypass channel inside the dam. Then the fish are shunted through a quarter-mile long pressurized pipeline to an area where they are separated by size. From there, they are placed in a holding tank and then put on trucks or barges and shipped downstream. The transportation of the smolts downstream on trucks or barges is a way for the migrating fish to completely bypass the dangers of contending with the dams that exist along the Columbia and Snake Rivers. On first glance, a bypass system appears to be an effective solution. By avoiding the dams, the smolts will have a better chance of survival because they do not have to confront potentially dangerous turbines and spillways. However, transporting the fish can cause them high levels of stress and result in high delayed mortality. Delayed mortality occurs when adverse conditions do not cause an immediate death, but rather delay death to a point later in the migration. Trucking or barging juvenile salmon downstream can have the following harmful effects on the fish:

- Physical Stress. The way in which the fish are physically handled in the transportation process can inflict injury and make them vulnerable to disease and predation once they are released back into the river. After being sucked through a pressurized pipe and crowded into a tank to be transported hundreds of miles, the juveniles can be disoriented and otherwise altered when returned to the river. If they are dazed in the river, they may have delayed avoidance responses, which reduces the reaction time of the juvenile salmon, making them easier targets for predators.

- Morphological Consequences. Transportation via barge or truck also throws off the timing of the juvenile salmon's arrival at the ocean. When traveling downstream on their own, it takes migrating smolrs at least a week to travel the hundreds of miles to reach the ocean. During the trip down the river, they go through morphological changes that allow them to survive the conditions of the ocean. Barging or trucking only takes a few days and it reduces their physiological adaptation to ocean conditions, sometimes resulting in delayed mortality in the ocean.

- Lack of Imprinting. A final way that transportation can decrease salmon survival is its effect on imprinting. Imprinting allows juvenile salmon to internally "map" their migration routes so that they are able to return to the same stretch of river where they were hatched in order to spawn. Being transported in a tank for hundreds of miles greatly interferes with the imprinting process, which, in turn, interferes with the ability for an adult salmon to migrate upstream.

Salmon transportation has been in practice for twenty years and the decline of the population continues. If the object of the policy is to recover the salmon populations, maintaining juvenile transportation as the primary activity of a conservation plan will not help to effectively achieve this objective. This sentiment was expressed in 1994 by the Independent Peer Review on fish barging programs, which found that "transportation alone, as presently conceived and implemented, is unlikely to halt or prevent the continued decline and extirpation of listed species of salmon in the Snake River." "2

Current policies involving dam operations also inhibit the long-term chances for salmon survival. The four dams on the lower Snake River are in violation of the Clean W/ater Act by creating river conditions that are lethal to the salmon. National Marine Fisheries Service (NMFS) biologists have maintained that dam managers, usually the Army Corps of Engineers, must abide by certain water quality requirements. Under these regulations, 100,000 cubic feet per second of water must be released into the Snake River in the spring and the water temperatures of the river must not exceed 58 degrees. Unfortunately, the water quality requirements are not always met.

The adverse water quality conditions that can exist around the dams are often life threatening to the migrating salmon populations. In response to dam managers' failed compliance with the Clean Water Act, an alliance of environmental groups, including American Rivers, Trout Unlimited, and Environmental Defense, filed a lawsuit contending that the dams create slack water reservoirs where summer water temperatures can reach levels lethal to salmon. Furthermore, uncontrolled spilling of water over the dams' spillways can lead to high levels of nitrogen gas in the water during the spring, which also can be lethal to salmon. ${ }^{3}$

If the environmental interest groups win their case in U.S. 
District Court, the federal government will have to retrofit the dams in order to come into compliance with the Clean Water Act, primarily by ensuring that more water gets over the spillway. It has been estimated that this will cost approximately $\$ 450$ million. ${ }^{4}$ Additionally, since dams have a mechanical life of thirty to fifty years, they will soon need to be refurbished, at an approximate cost of \$100-200 million dollars. The total approximate cost of the changes that will be necessary to maintain the status quo is upwards of $\$ 500$ million. This is a considerable amount of money and thus constitutes a significant weakness in the policy of maintaining the dams. In contrast, a 1999 Army Corps of Engineers estimate of the total cost of dam removal, less the saved cost of refurbishing the generators, results in an annual cost amortized over fifty years of approximately $\$ 330$ million, considerably less than the cost of maintaining the current policy. ${ }^{5}$

The political and economic atmosphere surrounding the current policy is obviously complex in nature; so much so that it makes maintaining the status quo not only difficult, but also unfeasible. Even current measures that aim at salmon recovery have not had and are unlikely in the future to have a positive impact on the salmon populations. Vast resources have already been invested in transportation programs in the current recovery program. Since 1981, $\$ 3$ billion has been invested with no marked improvement in the status of the salmon. ${ }^{6}$ Some populations, like coho salmon, have actually gone extinct. Changes need to be made to the current policy to help ensure population recovery.

\section{Maximum Transport of Juvenile Salmon and Major System Improvements}

A popular alternative approach to this ecological, cultural, and economic crisis focuses on maximizing current transportation standards while providing additional attention and improvements to each stage of the salmon life cycle. ${ }^{7}$ This must be accomplished by using existing legislation such as the Endangered Species Act (ESA), technology, and manpower. Maximizing efficiency and streamlining management practices are key components of this approach, which attempts to rework current practices, but without the high financial commitment of the current policy. Some salmon recovery stakeholders and fisheries managers have embraced the comprehensive nature of this idea.

Addressing and resolving the 4- $\mathrm{H}$ problems is one aspect of this salmon recovery approach. Proponents of this approach offer ways to reduce the adverse effects of habitat degradation, overharvesting, and the effects of hatchery fish on wild salmon stocks. It is even believed that the hydrosystem itself can be reformed to provide salmon with greater chances of survival.

\section{Habitat}

Salmon habitats, no matter how degraded or fragmented from the impact of human development, must be integrated. Some species of salmon traverse more than twelve different habitat types in their life cycle. Degradation of any of these habitats can negatively impact salmon populations. ${ }^{8}$ It is possible to avoid these effects of habitat loss by collecting and transporting juvenile salmon to their final destinations. Improving and maximizing current transportation methods is therefore a central theme in this solution.

NMFS and the Army Corps of Engineers developed the current barging system in the 1970s. Current methods can collect upwards of 95 percent of young salmon in a given year, allowing them to completely bypass the "missing links" in their habitat chain. Promising new technology may further increase collection rates and barging abilities. However, despite technological improvements, barging remains problematic for the reasons outlined above. The Cumulative Risk Analysis (CRI), an analytical test used by NMFS to estimate the likelihood of extinction within specific time periods, indicated that increased transport of spring/summer chinook would slightly reduce their chances of extinction but that the overall increase would not be sufficient to achieve the NMFS recommended reduction in possible extinction for these species. ${ }^{2}$ Further complicating this approach, new technology or laws to encourage habitat improvements would inevitably affect the regulation of timber industry harvesting and road building, municipal and farm water withdrawal rates, and the use of household chemicals and fencing for cattle farmers, thereby generating new and complex political issues. ${ }^{10}$

\section{Hatcheries}

Hatcheries have played a key role in maintaining Snake River salmon populations at viable levels for over a century, and they should be not removed from the system. Rather, hatchery programs should continue to be reformed to focus more attentively on local and natural populations of salmon.

Significant reforms have been implemented to help advance the new goals of hatchery management. For example, hatchery steelhead, coho, and chinook are being "tagged" so that fishers can identify them easily and can release them among unmarked wild salmon. " To their credit, a handful of hatchery managers, reacting to the growing concern that artificial production can cause genetic and ecological harm to 
wild stocks, have also placed increasing emphasis on wild stocks and naturally spawning stocks as populations have declined. Such managers will help ensure that hatchery fish do not out-compete wild stocks for food or quality habitats.

These practices should be emulated throughout the hatchery industry. In order to maximize the positive affects of hatcheries, hatchery managers need to employ all available technology and encourage future innovation so that hatchery salmon remain identifiable from their wild cousins. At present, though, the majority of hatcheries simply do not lend themselves to the recovery of wild salmon. Regional hatcheries have not satisfied the objective of sustaining production; today, state policies, court orders, treaties, mitigation agreements, and annual harvest negotiations come into play in decisions regarding hatcheries. Hatcheries are part of the long-term solution to this crisis, but industry-wide changes are needed.

\section{Harvest}

Harvest rates have been regulated on the Snake River to ensure only 5-20 percent of in-river runs are taken. It is important to note that these "take" quotas for salmon have been in place for the past fifteen to twenty years and are not always considered effective in salmon recovery by the goveinment or the scientific community. ${ }^{12}$ Quotas for ocean harvests are a different story, and most proposed harvest reductions target ocean populations of salmon. ${ }^{13}$ One commonly suggested regulatory measure is to reduce commercial ocean harvests further than current quotas allow or ban harvesting entirely for a period of ten years, while maintaining tribal fishing rights. However, restricting both in-river and ocean harvest take quotas will be politically difficult. Governor Knowles of Alaska, a very influential stakeholder in this debate, is opposed to harvest limits because of the dependency of the Alaskan economy on salmon harvesting. Predator populations, such as Caspian terns, are also considered a "harvest" concern; it is estimated that the terns consume (or harvest) six to twenty million (3-12 percent) of the salmon runs each spring. ${ }^{14}$ It may be possible to reduce the impact of these predators on the salmon juveniles by developing a policy to relocate the birds to an area where they will have less contact with salmon. The tern situation is problematic, though, because they are protected under the Migratory Bird Treaty Act in the habitats where they do the most damage to salmon populations.

An additional concern is that current policies, like barging, exacerbate the impact of salmon predators. Research shows that when salmon are barged downstream they are traumatized and at greater risk to predators because they hover at the surface of the water to recover. ${ }^{15}$ Therefore, if salmon are not barged downstream, their predation may be reduced since they would swim deeper in the water and would not need to rest in the waters near Caspian tern habitat.

\section{Hydropower}

The hydropower systems on the Snake River can be adjusted to increase the velocity of water flowing through them. There is little dispute that increased water flow will greatly benefit salmon and their habitats. There are two ways to accomplish this objective. First, flow augmentation can amplify the velocity of water by increasing the Snake River volume using contributions from up-river dams. In order to obtain the ideal velocity, an average of one million acre-feet of water must be drawn from up river dams in Idaho. Alternatively, "drawing-down" the reservoirs so that their cross-sections are decreased will force the same amount of water through a smaller area, increasing water velocity by a different means. ${ }^{16}$

\section{Possible Benefits of the "4-H" Approach}

There are obvious benefits in addressing the crises with a combination of the solutions discussed above. First, it would be palatable to influential political stakeholders. Oregon Representatives Peter DeFazio and Greg Walden have endorsed increased funding for salmon screens to prevent salmon from entering certain degraded or dangerous habitats. Their endorsement represents a constituency thac wishes to use the latest technology as a means for preserving habitat. ${ }^{17}$ Washington State's Senator Gorton and Governor Locke have voiced opposition to dam breaching and therefore might endorse alternatives, such as fish screens.

Second, this approach maximizes transport of juvenile salmon and provides for major system improvements, addresses the 4- $\mathrm{H}$ 's and is a positive step towards improving salmon survivability. Such a comprehensive management scheme addressing all four parts of the problem is growing more and more important in modern environmental management. Because of this, it would seem that this solution could be successful in achieving the goals set by NMFS and special interest groups, the most important of which is extinction prevention.

\section{Possible Problems with this Approach to Salmon Recovery}

While this solution appears to be comprehensive, it is not complete: Salmon have endured in the Pacific Northwest for thousands of years as part of a natural system. ${ }^{18}$ Attempting to restore their population numbers with tech- 
nology may not ensure the long-term survival of the species because it will provide for artificially based life cycle, rather than natural management. Moreover, technological solutions have failed to improve the viability of the Snake River salmon population, and indeed, in many instances, they have encouraged its deterioration,

The primary criticisms of this approach come from the scientific community; no concrete evidence can prove this solution will actually provide for the recovery of the endangered salmon populations. The Plan for Analyzing and Testing Hypothesis (PATH) report studies biological effectiveness associated with the various solutions. Reflecting the work of state, tribal, federal, and independent scientists from within and outside the Northwest region, PATH indicated that this solution would have an effect similar on salmon populations to current strategies, i.e. that it will not significantly improve the life cycles of local resident fish such as northern pikeminnows, rainbow trout, common carp, smallmouth bass, crappies, catfish/bullfish, and yellow perch. ${ }^{19}$ Thus, while this integrative approach contains elements of a holistic solution, it falls short of meeting the objective of preventing extinction.

\section{Aggressive Non-Breach}

Another possible alternative to the current policy is an "aggressive non-breach" approach. This alternative utilizes various parts of other possible approaches and is derived from the National Marine Fisheries Service's 4-H working paper. An aggressive non-breach would defer a decision on dam breaching and allow for an interim period to determine whether aggressive actions in all of the 4-Hs (habitat, harvest, hatcheries, and hydropower) are likely to recover Snake River fish and to resolve any scientific uncertainty. ${ }^{20}$ Under this approach, the dams would not be breached, but improved fish passage facilities and flow augmentation would be provided for. Funding would be increased in order to implement changes in fish passage through the dams to increase the survival of migrating salmon. This approach would require state and local governments to contribute funds to habitat protection along the Snake River and, if necessary, hatcheries would have an increased role in salmon recovery efforts. Finally, harvest rates would be restricted to conservation fishery levels; therefore, harvest impacts on listed populations would be reduced to conservation crisis levels for a period of years, after which the regime would shift to less strict levels.
Potential Benefits of Aggressive Nonbreaching

An aggressive non-breach program could be moderarely effective as a recovery plan since its focus is on flow augmentation and increased spill that would help get the salmon over the dams. In order to increase the volume and velocity of water that goes over the spillway, the flow of the river must be similarly increased. There is mixed opinion as to whether spill is a relatively safe and effective way to transport smolts past the dams. Some scientists argue that the mortality of salmon that are spilled over dams is insignificant. It was found, for instance, that the mortality of chinook that were spilled over McNary Dam (Columbia River) and Big Cliff Dam (Santiam River) was less than 2 percent. ${ }^{21}$ Others maintain that the Gas Bubble Trauma (GBT) that can result from exposure to gas supersaturated water (water with a high level of dissolved gas) results in higher mortality than reported. If salmon are exposed to too much nitrogen while going over dams, the effects can range from impaired swimming performance to death. William Steele, Jr., Director of the Northwest Region of NMFS, testified before Congress in 1995 that states' concerns over GBT have been significant enough to spur adoption of water quality standards consistent with EPA guidelines. ${ }^{22}$

Through this approach, state and local governments would increase funding for habitat protection and a coordinated regional plan for management. A coordinated regional effort would help to ensure a more comprehensive and holistic recovery plan. By stepping up the amount of resources invested in this program (relative to the current policy and that of maximizing current systems) it is hoped that the population levels of endangered and threatened species would increase. Efforts to recover salmon could provide other benefits; if recovery managers can similarly develop surface bypass systems that work to guide fish away from turbines and minimize stress on the fish, then the efficiency of the hydropower system can be increased. Currently, efforts are focused on turbine passage improvements. One result of these efforts is that a minimum gap runner is being tested as part of the Bonneville Dam rehabilitation projects. If this and other technology proves to be effective in decreasing mortality of smolts migrating down river, then a big step towards the recovery of salmon populations might be achieved.

\section{Potential Problems with Aggressive Nonbreaching}

While the increased role of hatcheries in this approach has the potential to be beneficial to the program, it could also exacerbate the crisis if hatcheries continue to replenish stocks that do not have some wild genes. According to the Salmon Recovery Group's report, Life Cycle Analysis, for hatcheries 
to work, they should not simply pump more and more fish into the rivers to compete with wild fish or provide commercial fisheries with more fish to catch in the open ocean. Instead, hatchery efforts should augment recovery efforts by maintaining genetically diverse strains of wild stock from local streams. ${ }^{23}$ This would mark a concerted effort to maintain salmon populations that have the genes that provide them with the ability to survive in the wild.

This program could also face budgetary problems. The NMFS has been unable to complete their assigned task of recovering salmon with available funding. ${ }^{24}$ If an aggressive non-breach approach is implemented, it is going to require additional federal and state funding in order for it to be successful. Without adequate funding, the necessary habitat assessments, planning, implementation, and monitoring will nor be accomplished. However, the annual process of appropriating federal funds to agencies is long, drawnout, and difficult. Allocating the billions of dollars already spent on this issue itself has been difficult; finding additional money for a potentially indefinite amount of time could prove to be next to impossible.

\section{Dam Removal}

Dam removal, also known as breaching or bypassing, directly eliminates two major obstacles facing salmon during migration: passage through the four dams on the Lower Snake River and passage through the reservoirs created by those dams. The term "dam removal" itself is a bit misleading, however. Common practice with dam removal is to remove only the earthen section of the dam (approximately half of the cross section of the dam), leaving the mechanized section inoperative but in place on the river. This is significantly less expensive than removing the entire structure and would re-create 140 miles of free flowing river and habitat,

The issue of dam removal is complex because of its drastic implications. The four dams generate power that contributes to low electric bills and supplies water for irrigation for the entire Pacific Northwest region. The Snake River is also a major mode of transportation in the region.

However, dam removal will affect more than salmon, electric bills, and transportation. Many regional areas have been witness to the transformation of relatively small towns into bustling ports. Lewiston, Idaho is one town that will be greatly impacted by dam removal. At present, Lewiston is the farthest upriver port on the Snake River, and serves as a hub of commerce for the region and its inhabitants. If the dams are removed, Lewiston will lose its primary means of economic subsistence.

\section{Impacts of Dams on Salmon}

Salmon must pass through the four dams on the Lower Snake River twice in their lifetime. There are myriad problems faced by the fish because of the current hydropower systems. Adult salmon swimming upstream to spawn must utilize fish ladders to get over dams. With narrow entrances that are often difficult to find and high water temperatures, the step-like fish ladders can be fatal to salmon. Once fish reach the top of the ladder, they must avoid "fallback," being swept back over the dam spillway and into the electricity producing turbines. These turbines can either tear the fish apart or de-scale them, leaving them vulnerable to disease. Even though juvenile salmon bypass systems exist on the dams in order to minimize the aforementioned problems, being flushed through the high-pressure pipes of these systems traumatizes the young fish, leaving them easy targets for predators. ${ }^{25}$ Finally, passage through reservoirs created by dams can be dangerous for salmon. Reservoirs have slowed the river currents so significantly that migration, which in the past took anywhere between five to ten days, now takes one to two months. ${ }^{26}$ High temperatures in the reservoirs during spring and summer months are dangerous; temperatures of over $80^{\circ} \mathrm{F}$ are a full $10^{\circ} \mathrm{F}$ higher than salmon can tolerate. Overall, the NMFS estimates that 21 39 percent of salmon die while passing through the ladders and reservoirs. ${ }^{27}$ The successful adults that do reach their spawning grounds are often too exhausted to reproduce.

\section{Potential Benefits of Dam Removal}

The high effectiveness of breaching the dams in terms of salmon recovery is evidenced by data compiled from a number of scientific studies. The Independent Scientific Advisory Board (ISAB), a group of independent scientists commissioned by the Clinton Administration, issued a report, Return to the River, in 1996 stating that, "migration conditions in the Snake River must be returned toward those under which salmon evolved and thrived." 28 The final PATH report, released in 1998 and incorporating thirty years of scientific study, determined that the dams should be removed. ${ }^{29}$ There is widespread popular support for breaching as well. Over 230 regional and national special interest groups, including Native American tribes, conservationists, fishermen, businesses, and taxpayers, endorse breaching. ${ }^{30}$ Breaching would also benefit other wildlife species, such as raccoons and otters, but could negatively affect game birds, small mammals, and others dependent on reservoir conditions. 
Breaching the four Lower Snake River dams would be a highly effective way to revive salmon populations. The PATH report concluded that dam bypass would re-create more than one hundred forty miles of spawning habitat lost since the construction of the darns decades ago. ${ }^{31}$ Furthermore, history has proven dam removal to be effective. In 1934, fishermen sent a raft loaded with dynamite into Sunbeam Dam on the upper Snake River, setting that section of the river free for the first time in over twenty-five years. Salmon returned to the streams above the dam almost immediately and reached sustainable levels within twenty years. ${ }^{32}$ The recent removal of the Edwards Dam on the Kennebec River in Maine has had positive effects on local threatened fish populations and has reinvigorated those who favor dam removal. ${ }^{33}$ In September of 1999, it was decided that the Condit Dam on the White Salmon River would be removed, returning the river to resident salmon. A staff member from Governor Gary Locke's office commented on this decision: "Barriers, like Condit, that keep fish from reaching their spawning grounds are the kinds of problems we are going to need to continue to address." 34

Dam removal would eliminate the aforementioned obstacles facing salmon on the lower Snake River. Many other benefits exist. An important economic benefit to be gained from bypassing the Snake River dams is the restoration of commercial, sport, and tribal fishing that depends on healthy salmon and steelhead runs. The Idabo Statesman, a Boisebased newspaper, estimated increased economic benefits from healthy fisheries at $\$ 248$ million per year in Idaho alone. Commercial fishermen would see a more fish-friendly river bringing in five thousand new jobs and $\$ 100$ million in annual revenue to downriver fishing cities such as Astoria. Recreation and tourism revenues from anglers, kayaks, canoeists, jet-boaters, rafters and tourists would increase by $\$ 67$ million dollars. ${ }^{35}$ Coastal and rural communities in a wide geographic region including Oregon, Washington, and Alaska could be rejuvenated by such economic growth. ${ }^{36}$

Yet another noteworthy benefit stems from the fact that the four dams will soon be due for major renovation. Removing the dams will make such expensive routine maintenance repair unnecessary and save nearly $\$ 420$ million. Operation costs, estimated at $\$ 34$ million per year, will no longer need to be expended, and millions could potentially be saved with the end of expensive and continuous technological fixes, and navigation and agricultural subsidies. ${ }^{37}$

\section{Potential Problems with Dam Removal}

Dam removal is costly and complex. Approximately seven million cubic yards of rock and soil will be scraped away from the four dams and hauled to new locations. Fortyfour miles of rails and roadbed will need buttressing against a lower, faster Snake River. Twenty-five bridge piers will require reinforcement. Twenty-seven of thirty-three boataccess sites would be moved. ${ }^{38}$ Reinforcing riverside roadbeds and removing the earthen sections of the dams could cost $\$ 1$ billion, with $\$ 315$ million to be expended in railroads and highways to accommodate traffic. The Bonneville Power Company, which sells $\$ 250$ million worth of electricity a year and generates about 5 percent of the region's electricity, stands to lose 3,033 megawatts of electricity. This could translate into higher rates for consumers of $\$ 1.20$ to $\$ 6.50$ per month. (Residents would still enjoy the lowest rates in the country). ${ }^{39}$

As noted above, the Snake River is a major Northwest shipping route where roughly 3.8 million tons of grain, petroleum, logs, wood chips, wood products, and lesser commodities are barged to deepwater ports on the Lower Columbia River. The transportation sector of the Pacific Northwest will see great change and incur high financial costs if the dams are removed. Eliminating the locks that make traffic possible would mean that the commodities currently being shipped on the Snake River would be shipped via other modes, which would affect profound change in the costs of transport, storage, and handling of goods. Shipping costs are estimated to increase by 28 percent. ${ }^{40}$ Secondary effects will involve a change in shipping rates, rail line and cargo handling, and storage capacity.

These infrastructure changes, however, may also create new long-term employment opportunities. ${ }^{41}$ The net change in long-term jobs is estimated to be -711, less than 1 percent of employment in the lower Snake River region in 1995. The figures for the Pacific Northwest are similar, with the net change in long-term jobs, $-2,844$, or less than 0.1 percent of total employment in 1995.42 It has also been estimated, however, that breaching could create more than 3,100 recreation-related jobs and generate more than $\$ 200$ million in annual economic benefits. ${ }^{43}$

The politics surrounding dam removal are also complex. Alaska Governor Knowles appears to support dam breaching, and questions why Alaskans should cut back their salmon catch while Snake River dams remain in place, killing thousands of fish while providing people in the Northwest with cheap electricity, ${ }^{44}$ Support extends beyond the region, however. In an August 1999 letter, 107 members of the House of Representatives urged President Clinton to consider the dam removal alternative, noting that the future of 
Pacific salmon is a national issue. ${ }^{45}$ While this letter did not advocate dam removal, it insisted that it remain a viable option. The letter included the signatures of ninetyfive Democrats and twelve Republicans. Northwest signatories included Representatives Jay Inslee and Jim McDermott, and Representatives Earl Blumenauer, Peter DeFazio, Darlene Hooley and David Wu. ${ }^{46}$ Many tribal communities, scientists, special interest groups, and agriculturists have also weighed in. Given the highly political nature of the problem, it is likely that politics, and not science or economics, will ultimately dictate the solution.

\section{Conclusion}

What will provide the most effective, efficient, and feasible way to recover these salmon populations in a manner that equitably addresses the economic and cultural needs of the region? Based on our analysis, we conclude that the four dams on the Lower Snake River should be breached, as a first step.

Repeated studies have demonstrated that dams present the most serious obstacle for migrating salmon and that removing the dams will return a one-hundred forty mile free flowing stretch of river to the natural conditions under which salmon evolved and thrived. ${ }^{47}$ Many scientists agree that a river with fewer dams is likely to improve the survival of salmon as they migrate upstream and downstream ${ }^{48}$ by supporting conditions under which the salmon evolved. ${ }^{49}$

Dam removal is also the most financially sound long-term solution. As noted above, more than $\$ 3$ billion has already been expended on technological solutions that have only worsened conditions for the salmon populations. Reports assessing the economic costs of dam removal have shown salmon recovery options, such as new restrictions on farmers, loggers, and commercial fishermen, or maintaining the status quo, to be more costly than breaching. ${ }^{50}$ New financial investments should therefore first be made for the removal of the earthen portion of the dams, where long-term maintenance investments are not necessary. Specifically, investments should be made to counteract the lost transportation benefits of the dam by retrofitting existing rail lines.

Such an action is both the most efficient and effective solution.

However, breaching alone will be not effective. Not only do the dams need to be breached, but harvest, hatchery, and habitat impacts must also be promptly addressed. For ex- ample, conservation level harvest rates should be implemented for the next ten years and a coordinated regional effort should be organized in order to restore habitat. State and local government contributions could significantly improve in-stream flows and water management, irrigation improvements and riparian protections, and help to ensure habitat improvements. ${ }^{51}$ If hatchery managers continue with newly implemented regimes that employ adaptive management techniques, they can help ensure that hatcheries help and do not hinder salmon recovery efforts. ${ }^{52}$

Despite the more than $\$ 3$ billion spent during the past twenty years on salmon mitigation measures, Snake River salmon stocks have continued to decline to 90 percent below what they were before the dams were installed..$^{53}$ If salmon recovery efforts are not significantly expanded and reformed, threatened salmon and trout species could go extinct. The goal of any recovery plan should be the prevention of extinction and the recovery of healthy and harvestable populations. Breaching the dams is the critical first step in this plan.

\section{Notes}

' Columbia and Snake River Campaign. Saving Wild Salmon: Facts about bypassing dams on the lower Snake River, Overview.

${ }^{2}$ Philip Mundy, et al. Transportation of Juvenile Salmonids from Hydroelectric Projects in the Columbia River Basin: An Independent Peer Review, U.S. Fish and Wildlife Service, 1994.

${ }^{3}$ American Rivers Press Release, Lower Snake River Dams Violate Clean Water Act and Threaten Salmon, 31 March 1999.

${ }^{4}$ Personal communication with Tim Stearns of Save Our Wild Salmon, 19 October 1999.

'Columbia and Snake River Campaign. Saving Wild Salmon: Facts about bypassing dams on the lower Snake River, Salmon, dams and dollars.

'American Rivers Page. American Rivers. November 1999 <http:// amrivers.org/snakepast.html>.

${ }^{7}$ Commitree on Environment and Public. Works, Salmon Recovery on the Colombia and Snake Rivers, $105^{\text {th }}$ Cong., $2 d$ sess., 1998, 51-52.

${ }^{8}$ Ibid.

'US Army Corps of Engineers; Narional Marine Fisheries Service, Draft Lower Snake River Juvenile Salmon Migration Feasibility Study DEIS, Summary, 17 December 1999.

${ }^{10}$ National Salmon Recovery Working Group, personal correspondence from N. Fascione, October 1999.

"American Rivers Page. 10 January $2000<$ http://www.amrivers.org/ 
snakethreathatchery.htmls.

'Personal correspondence from Gerry Ring Erickson, February 2000.

${ }^{13}$ Committee on Environment and Public Works, 51-52.

${ }^{14}$ Senate Subcommittee on Water and Power, Lower Snake River Dams, $106^{\text {th }}$ Cong., $1^{\text {st }}$ sess., 1999, 12.

${ }^{15}$ Committee on Environment and Public Works, 1998, 12.

16 Senate Subcommittee on Water and Power, 12.

${ }^{17}$ Robert McClure, "Federal Study of Snake River Dam is in Error, Economist says." Seartle Post-Intelligencer, 16 November $1999<$ <www.seattlepi,com/local/salm04,htmls.

${ }^{18}$ Jim Lichatowich, Salmon without Rivers (Washington DC: Island Press, 1999).

${ }^{19}$ US Army Corps of Engineers.

${ }^{20}$ National Marine Fisheries Service, Conservation of Columbia Basin Fish: Building a Conceptual Recovery Plan with the Four Hs - Working Paper, November 1999, 14.

${ }^{21}$ National Research Council, Upstream (Washington, D.C.: National Academy Press, 1996).

"Subcommittee on Drinking Water, Fisheries, and Wildlife, Salmon Spill

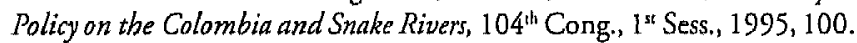

${ }^{23} \mathrm{~W} . \mathrm{H}$. Fawcett and James Tate, $\mathrm{PhD}$, A Life Cycle Solution for Salmon (The Salmon Recovery Group, 1999).

${ }^{24}$ Ibid.

${ }^{25}$ Subcommittee on Drinking Water, Fisheries, and Wildlife, 27.

${ }^{26}$ Columbia and Snake River Campaign. Saving Wild Salmon: Facts about bypassing dams on the lower Snake River. Biology and History of Snake River salmon.

${ }^{27}$ US Army Corps of Engineers.

${ }^{28}$ Columbia and Snake River Campaign.

${ }^{29}$ The Columbia and Snake River Campaign, Saving Wild Salmon: Facts about bypassing dams on the lower Snake River. The Science of Dam Removal.

${ }^{30}$ American Rivers Page, <www.amrivers.org>.

"Columbia and Snake River Campaign.

${ }^{32}$ Ibid.

33 "A. First for State: Big Dam to be Torn Down" Seattle Post, 23 September 1999

${ }^{34}$ American Rivers, <http://www.amrivers.org/conditdam-press $922 . \mathrm{html}$.
${ }^{35}<$ http://www,oregonlive.com/s.

${ }^{36}$ American Rivers, <http://www.amrivers.org/

snakeeconomicsbenefits.html>.

${ }^{37}$ Colombia and Snake River Campaign.

${ }^{38}$ Ibid.

39 $<$ htcp://www.oregonlive.com/>.

${ }^{40}$ Lower Snake River Juyenile Salmon Migration Feasibility Study. Economic Appendix, Transportation Analysis. Study by Drawdown Regional Economic Workgroup.

${ }^{41}$ American Rivers Page, <http://www.amrivers.orgs.

42 US Army Corps of Engineers.

$4,3<$ htrp://www.oregonlive.com/>.

${ }^{44}$ Federal Study of Snake dams is in error, economist says." Seattle P-I

${ }^{45}<$ www.seatdep-i/national/dams05.shtml>.

${ }^{46}$ Ibid.

${ }^{47}$ Columbia and Snake River Campaign.

${ }^{48} \mathrm{Ibid}$.

4) James Buchal, The Great Salmon Hoax (Oregon: Iconoclast Publishing, 1998) 219.

${ }^{50}$ Drawdown Regional Economic Workgroup.

51 American Rivers Page, <http://www.amrivers.org >.

52 American Rivers Page, November 1999. <http://www.amrivers.org/ snakethreathatchery.html>.

${ }^{53} \mathrm{Jim}$ Lichatowich, Salmon Without Rivers (Washington DC: Island Press, 1999).

\section{Bibliography}

American Rivers. Irrigation After Partial Removal of the Four Lower Snake River Dams. November 1999 <http://www.amrivers.org.>

American Rivers (Press Release). Lower Snake River Dam Violate Clean Water Act and Threaten Salmon. 14 March 1999 <http:// www.amrivers.org/salmon -press $2 . \mathrm{h} \mathrm{rml}$.

American Rivers. Returning Salmon by Restoring Rivers. 14 October 1999 $<$ http://www.amrivers.org/snakereport.htmls.

American Rivers Page, Snake River Salmon Threats - Hatchery Raised Salmon. November 1999. <http://www.amrivers.org/ snakethreathatchery.htmb.

American Rivers (Press Release). Northwest Salmon Managers Get Failing Grades. 6 October 1999 <http://www.amrivers.org/ 
snakereportcard99.htmls.

Anderon, Witt, et al. Fish and Wildlife Recovery in the Pacific Northwest: Breaking the Deadlock. A Draft Analysis by the Northwest Power Planning Council Staff. 10 October 1999 <http:// www.nwppc,org/breakng.htm>.

Associated Press. Bill would belp farmers build salmon screens. 10 November 1999 <http:/www.djc.com/news/enviro/10060552.html>.

Barnett, Jim. BPA can't raise rates to fund dam removal. The Oregonian 9 September 1999. <http://www.oregonlive.com/news/99/09/ st093007.hrml>.

Blumm, Michael C., ct al. "Saving Snake River Water and Salmon simultaneously: the biological, economic, and legal case for breaching the lower Snake River dams, lowering John Day Reservoir, and restoring natural river flows". Environmental Law 28 (Winter 1998): 997.

Brinckman, Jonathan. "Oregon Backs Lawsuit on Snake River Warer" The Oregonian, 11/2/99 <www.oregonlive.com> (11/3/99).

Buchal, James, The Great Salmon Hoax. An Eyewitness Account of the Collapse of Science and Law and the Triumph of Politics in Salmon Recovery. Oregon: Iconoclast Publishing, 1998.

Columbia and Snake Rivers Campaign. Saving Wild Salmon: Facts about bypassing dams on the lower Snake River. Informational Folder, 1999

Columbia and Snake Rivers Campaign. Young Salmon Need to Migrate in Rivers-Not in Barges. 16 November 1999 <http:/l www.removedams.org

Defenders of Wildlife Page, March 2000, <http://www.defenders.org>.

Erickson, Gerry Ring, personal correspondence, February 2000.

Fawcett, W.H., James'Tate, PhD. A Life Cycle Solution for Salmon, Salmon Recovery Group, January 1999.

Hays, Justin. Snake River Dam Removal Transportation Transitional Plan Released. 13 October 1999 <http://www.amrivers.org/ snakedam-press.html>.

Lichatowich, Jim. Salmon without Rivers: A History of the Pacific Salmon Crisis. Washington DC: Island Press, 1999.

National Research Council. Upstream: Salmon and Society in the Pacific Northwest. National Academy Press: Washington, D.C., 1996.

Mundy, Philip, et al. "Transportation of Juvenile Salmonids from Hydroelectric Projects in the Columbia River Basin: An Independent Peer Review" U.S. Fish and Wildlife Service, 1994.

McAboy, Kell. Personal email correspondence, February 2000.

McClure, Robert. Federal Study of Snake dams is in error, economist says. Seatrle P-I, 16 November 1999. <http://www.seartle-pi.com/ local/salmo $4 . \mathrm{html}$.
National Marine Fisheries Service. Conservation of Columbia Basin Fish, Building a Conceptual Recovery Plan with the Four Hs - A Working Paper. November 1999.

N. Fascione, National Salmon Recovery Working Group, personal correspondence October 1999.

Paulson, Michael. "A First for State: Big Dam to be Torn Doun; It's Cheaper than Price of Fish Ladders." Seattle P-I, 23 September 99.

Salmon Facts: Perspectives on Pacific Salmon. Flier published by the Canadian Consulate General.

Tryon, LeeAnne, Dams, Energy and Salmon. Columbia \& Snake Rivers Campaign with NW Energy Coalition.

US Army Corps of Engineers and National Marine Fisheries Service. Draft Lower Snake River Juvenile Salmon Migration Feasibility Study DEIS. 17 December 1999.

U.S. Senate Subcommittee on Drinking Water, Fisheries, and Wildlife of the Committee on Environment and Public Works. Salmon and Steelhead Recovery in the Pacific Northwest, 104th Cong,, $2^{\text {ud }}$ sess., S. Hrg. 104-732, 11 June 1996.

U.S. Senare Subcommitree on Drinking Water, Fisheries, and Wildlife of the Committee on Environment and Public Works. Salmon Recovery on the Columbia and Snake Rivers, $105^{\text {th }}$ Cong., $2^{\text {md }}$ sess., S. Hrg. 105-944, 8 October 1998.

U.S. Senate Subcommitree on Drinking Warer, Eisheries, and Wildlife of the Commirtee on Environment and Public Works. Salmon Spill Policy on the Columbia and Snake Rivers, 104th Cong., $2^{\text {mul }}$ sess., 22 June 1996.

U.S. House Subcommittee on Water and Power, Lower Snake River Dams, 106 $6^{\text {th }}$ Cong., $1^{\text {st }}$ sess., 1999, 12.

Vogel, David. National Styles of Regulation: Environmental Policy in Great Britian and the United States. Ithica: Cornell Universitity Publishers, 1986. 
